\title{
ANALISIS SIKAP ILMIAH MAHASISWA CALON GURU IPA PADA MATA KULIAH BIOLOGI DASAR I
}

\section{THE ANALYSIS OF THE SICIENCE ATTITUDE STUDENTS OF SCIENCE EDUCATION IN BASIC BIOLOGY I}

\author{
Desi Nuzul Agnafia ${ }^{1}$, Hanin Fauziah ${ }^{2}$, Susdarwati ${ }^{1}$ \\ ${ }^{1}$ STKIP Modern Ngawi, Jl. Ahmad Yani No.99, Beran I, Beran, Kec. Ngawi, Kabupaten Ngawi, Jawa Timur 63216, Indonesia \\ ${ }^{2}$ IAIN Ponorogo, J1. Puspita Jaya, Krajan, Pintu, Kec. Jenangan, Kabupaten Ponorogo, Jawa Timur 63492, Indonesia \\ *Corresponding authors: desiagnaf@gmail.com \\ Manuscript received: ......... Revision accepted:
}

\begin{abstract}
This research has purpose to analyze the scientific attitude of students in basic bology I. This research is a descriptive research. The subject of research is student of science education STKIP Modern Ngawi first semester in the academic year 2018/2019. Attitude was measure used a questionnaire of scientific attitudes..The percentages of students curiosity attitude $78,84 \%$ with good criteria, responsibility accurary was $71,15 \%$ with good criteria, conscientious atitude was $71,63 \%$ with good criteria, honesty attitude was $72,11 \%$ with good criteria, teamwork was $81,72 \%$ with good criteria, and ctitical attitude was $69,22 \%$ with ctireria enough. Overall, the percentage of the students scintific attitude was good criteria.
\end{abstract}

Keywords: Scientific attitude, Basic Biology

\section{PENDAHULUAN}

Proses perubahan sikap dan tingkah laku manusia menjadi lebih baik terus dilakukan melalui pendidikan. Pendidikan dijadikan kebutuhan yang utama bagi setiap manusia karena melalui pendidikan manusia dapat mengembangakan potensi dirinya untuk mencapai tujuan serta kesejahteraan hidupnya. Pendidikan sangat berperan penting untuk menjadikan sumber daya manusia yang berkualitas. Sumber Daya Manusia yang berkualitas diperlukan untuk menyelesaikan tantangan yang baru dalam menghadapi era globalisasi. Pengembangan kualitas Sumber Daya Manusia tersebut dilakukan melalui perbaikan pendidikan. Perbaikan pendidikan dilakukan oleh pemerintah salah satunya penerapan kurikulum 2013 di sekolahan. Siswa harus menguasai kompetensi sesuai kurikulum 2013 yaitu mengembangkan rasa ingintahu, mengembangkan kreativitas, kemampuan berpikir kritis, kemampuan berpikir kreatif, serta memiliki sikap ilmiah dalam menghadapi persoalan ilmiah. .

Persoalan persoalan ilmiah perlu dilatihkan dan diterapkan pada mata pelajaran IPA. IPA merupakan bagian dari sains. Sains memiliki tiga aspek utama yaitu sains sebagai produk, sains sebagai proses dann sains sebagai sikap ilmiah. Sains sebagai produk yaitu merupakan ilmu yang mempelajari tentang fakta-fakta, konsep-konsep, maupun prinsip-prinsip materi secara teoritis yang dapat menjelaskan dan memahami alam serta fenomena yang terjadi didalamnya. Sains sebagai proses yaitu dalam memperoleh ilmu pengetahuan perlu adanya sejumlah keterampilan dalam membuktikan, menerapkan dan mengkaji fenomena alam dengan tahapan tertentu.
Sains sebagai sikap ilmiah yaitu sikap yang dimiliki para ilmuwan dalam menggali serta mengembangkan ilmu pengetahuan yang baru (Bundu, 2006).

Tiga aspek sains tersebut sesuai dengan kompetensi yang terkandung di dalam kurikulum 2013, sehingga dalam penilaian juga harus mengandung komponen dari ketiga aspek tersebut. Penilaian dalam pembelajaran yang dilakukan dalam kurikulum 2013 meliputi aspek pengetahuan, aspek keterampilan serta aspek sikap. Aspek penilaian terhadap siswa tidak hanya cukup diperoleh dari nilai ujian dari hasil menjelaskan serta mendengarkan materi dari guru saja, tetapi siswa yang aktif dalam proses menemukan sendiri atau membuktikan konsep akan lebih memahami materi yang disampaikan.

Proses pembelajaran di lapangan siswa dituntut secara aktif dalam menemukan konsep atau fakta melalui kegiatan observasi, eksperimen dan menyimpulkan data dari hasil yang diperoleh. Guru harus menguasai kompetensi kurikulum 2013 yang sesuai dengan materi yang disampaikan ke siswa agar dapat tercapai tujuan dari pendidikan. Mahasiswa sebagai calon guru IPA juga harus dibekali pembelajaran yang dapat mengembangkan proses kegiatan yang sudah di atur dalam kurikulum 2013.

Bagi siswa mata pelajaran IPA merupakan mata pelajaran sains yang menghendaki guru saat pembelajaran tidak hanya sebatas memberikan informasi bagi siswa tetapi berperan sebagai fasilitator juga. Kemampuan dalam melaksanakan peran tersebut harus dimiliki seseorang yang nantinya akan menjadi guru agar kelak dapat menumbuhkan hasil pembelajaran yang baik pada peserta didiknya. 
Upaya dalam mempersiapkan calon guru yang berkompeten di bidang sains, perlu dilakukan penelusuran terlebih dahulu terkait aspek yang berhubungan dengan kemampuan sains. Salah satunya adalah sikap dasar yang harus dimiliki oleh para calon guru ipa yaitu sikap ilmiah. Sebagai calon guru mereka harus mempersiapkan terlebih dahulu sikap positif karena nantinya akan menjadi teladan bagi peserta didiknya. Sikap ilmiah perlu dikembangkan dalam pembelajaran sains hal ini sesuai dengan hakikat sains bahwa tingkah laku ilmiah didasarkan dan dimotivasi oleh sikap ilmiah.

Sikap ilmiah merupakan sikap yang dibentuk oleh seseorang yang bergerak dalam bidang ilmu alamiah dan bersifat ilmiah. Sikap ilmiah merupakan hasil dari kegiatan belajar yang diperoe melalui pengalamana, pembelajaran, identifikasi, peran disekitar, pembelajaran. Sikap dapat berubah secara intensif karena adanaya kegiatan pengalaman baru yang dilakukan secara rutin (Abdi, 2015)

Siswa harus memiliki sikap ilmiah dalam melakukan kegiatan ilmiah. Kegiatan ilmiah dilakukan melalui pengamatan, observasi, megkomunikasikan, mengukur dan lainnya. Sikap ilmiah perlu dikembangkan dalam kegaiatan pembelajaran karena dapat melatih sikap berani dan santun dalam beragumentasi dan bertanya, rasa ingin tahu, bekerjasama, disiplin, jujur, kritis, objektif, cerrmat, kreatif, dan beretos kerja. Carin juga menyatakan bahwa sikap ilmiah diantaranya rasa ingin tahu, mengutamakan bukti, skeptis atau tidak mudah percaya, menerima perbedaan, bekerjasama, bersikap positif terhadap kegagalan (Marlina, 2013).

Biologi merupakan salah satu cabang dari ilmu pengetahuan alam. Biologi Dasar I merupakan mata kuliah dasar yang harus ditempuh oleh calon guru ipa. Tujuan mata kuliah Biologi Dasar I diharapkan mahasiswa mampu memahami konsep konsep dan prinsip dasar biologi serta mampu menerapkannya dengan ilmu lain sehingga mahasiswa memiliki wawasan biologi secara ,menyeluruh. Mata kuliah biologi dasar I yang diimplementasikan pada calon guru ipa harus dilakukan sesuai hakikat sains.

Salah satu aspek dalam sains yaitu aspek sikap yang diterapkan dalam pembelajaran adalah sikap ilmiah. Sikap ilmiah merupakan hasil terpenting dalam pembelajaran biologi yang termasuk ilmu sains dimana sikap ilmiah dianggap sama dengan pengetahuan ilmiah (Zulirfan, Zanaton H. Iksan, Kamisah Osman, 2017). Biologi dalam proses pembelajarannya banyak dilakukan proses kegiatan eksperimen dalam membantu mengembangkan sikap ilmiah. Tujuan yang akan dicapai dalam penerapan pembelajaran biologi adalah adanya pengembangan sikap ilmiah yang dimiliki oleh setiap siswa sehingga mahasiswa calon guru juga mempersiapkan diri dalam pengembangan pembelajaran yang mencakup aspek sikap ilmiah. Pembelajaran yang dapat menmunculkan sikap ilmiah salah satunya dengan praktikum (Suryani, 2016).

Pentingnya sikap ilmiah yang harus dimiliki oleh para peserta didik mengharuskan mahasiswa calon guru ipa untuk dapat memahamai, menguasai, dan memiliki sikap ilmiah pada dirinya sendiri sehingga pada pembelajaran perkuliahan perlu dimotivasi untuk mengembangkan sikap ilmiah tersebut. Upaya dalam mempersiapkan calon guru yang memiliki sikap ilmiah, maka perlu dilakukan penelitian untuk mengetahui sikap ilmiah mahasiswa calon guru ipa pada pembelajaran biologi dasar I.

\section{METODOLOGI PENELITIAN}

Penelitian ini merupakan jenis penelitian deskriptif yang merupakan penelitian untuk menggali data kondisi yang sebenarnya. Penelitian deskriptif menjelaskan suatu kondisi yang terjadi sebenarnya, tidak ada penambahan variabel bebas serta tidak ada manipulasi sehingga menggambarkan situasi yang sebenarnya (Suharsimi, 2013). Penelitian ini memberikan gambaran tentang sikap ilmiah calon guru ipa pada praktikum Biologi Dasar I tahun akademik 2018/2019. Penelitian dilaksanakan di STKIP Modern Ngawi pada program studi pendidikan ipa angkatan 2018 dengan jumlah mahasiswa 26 orang. Penelitian dilakukan pada bulan September sampai November 2018.

Deskripsi kemampuan sikap ilmiah mahasiwa diperoleh dari hasil observasi yang dilakukan dengan menggunakan indikator indikator yang telah ditetapkan. Indikator sikap ilmiah yang diterapkan dalam penelitian ini yaitu sikap rasa igin tahu, sikap tanggung jawab, sikap kerjasama, sikap teliti, sikap jujur, dan skap kritis.

Observasi dilakukan oleh observer yang telah ditentukan dan diberikan kesamaan konsep dalam melakukan observasi sikap ilmiah pada mahasiswa. Observer terdiri dari 3 orang yang melakukan pengamatan semua siswa sesuai indikator sikap ilmiah. Hasil dari observasi akan dianalisis berdasarkan jumlah perolehan skor setiap mahaiswa kemudian ditentukan kriteria nilai sikap ilmiah. Tabel.1 merupakan pedoman kriteria dari nilai sikap ilmiah.

Tabel 1. Kriteria Nilai Sikap Ilmiah

\begin{tabular}{cc}
\hline Nilai & Kriteria \\
\hline $\mathbf{8 1}---\mathbf{1 0 0}$ & Sangat Baik \\
\hline $\mathbf{7 1}---\mathbf{8 0}$ & Baik \\
\hline $\mathbf{6 1}---\mathbf{7 0}$ & Cukup \\
\hline $\mathbf{5 1}--\mathbf{6 0}$ & Kurang \\
\hline$<\mathbf{5 1}$ & Kurang Sekali \\
\hline
\end{tabular}

(Riduwan, 2009)

Tahapan yang dilakukan dalam penelitian meliputi tahap awal, tahap inti, dan tahap akhir. Tahap pertama yaitu tahapan awal dengan melaksanakan observasi awal dan membuat rancangan penelitian, setelah itu menyusun instrumen dari penelitian. Tahap selanjutnya yaitu tahapan dilapangan dengan menerapkan kegiatan pembelajaran praktikum pada mata kuliah Biologi Dasar I kepada mahasiswa dan melakukan kegiatan observasi dengan indikator yang telah ditetapkan. Tahap akhir dilakukan dengan menganalisis data dari observasi yang diperoleh. Data di analisis sesuai dengan motode analisis yang 
digunakan, hasil dari annalsiis kemudian dibuat simpulan. Tahapan selanjutnya kemudian menyusun laporan dari hasil penelitian analisis sikap ilmiah.

\section{HASIL PENELITIAN DAN PEMBAHASAN}

Berdasarkan analisis data diperoleh hasil bahwa rata rata sikap ilmiah dari mahasiswa calon guru ipa. Indikator sikap ilmiah yang digunakan dalam penelitian ini yaitu rasa ingin tahu, tanggung jawab, jujur, disiplin, kerjasama, dan kritis. Hasil analisis data sikap ilmiah pada calon guru IPA disajikan berdasarkan persentase rata-rata di kelas. Sikap ilmiah para calon guru ipa pada praktikum biologi dasar I dapat dilihat pada Tabel 2.

Tabel 2. Rata - Rata Sikap Ilmiah pada setiap pertemua Calon Guru IPA dalam mata kuliah Biologi Dasar I

\begin{tabular}{ccccc}
\hline Indikator Sikap IImiah & \multicolumn{5}{c}{ Peretemuan ke- } \\
\hline & 1 & 2 & 3 & 4 \\
\hline Rasa Ingin Tahu & 81.73 & 80.76 & 75.96 & 76.92 \\
& & & 71.15 & 72.11 \\
\hline Tanggung Jawab & 70.19 & 71.15 & 72.11 & 73,07 \\
\hline Teliti & & & 72.11 & 72.11 \\
\hline Jujur & 71.15 & 70.15 & 81.73 & 82.69 \\
\hline Kerjasama & 70.19 & 71.15 & 70.19 & 71.15 \\
\hline
\end{tabular}

Tabel 3. Kriteria Rata-Rata Sikap Ilmiah Calon Guru IPA dalam praktikum Biologi Dasar I

\begin{tabular}{lll}
\hline Sikap Ilmiah & Rata -rata & Kriteria \\
\hline Rasa Ingin Tahu & 78.84 & Baik \\
\hline Tanggung Jawab & 71.15 & Baik \\
\hline Teliti & 71,63 & Baik \\
\hline Jujur & 72,11 & Baik \\
\hline Kerjasama & 81.72 & Baik \\
\hline Kritis & 69,22 & Sangat Baik \\
\hline Rata-rata sikap ilmiah keseluruhan & $\mathbf{7 4 , 1 1}$ & Baik \\
\hline
\end{tabular}

Berdasarkan Tabel 2 dan Tabel 3 menunjukkan persentase rata-rata dan kriteria sikap ilmiah pada calon guru ipa atau mahasiswa program studi ipa diperoleh hasil dengan persentase yang berbeda-beda. Sikap ilmiah kerjasama memperoleh hasil persentase paling tinggi dibandingkan sikap ilmiah yang lain yaitu sebesar $81,72 \%$ dengan kriteria kriteria sangat baik. Sikap ilmiah rasa ingin tahu memperoleh hasil tertinggi kedua dengan persentase $78,84 \%$. Sikap jujur sebesar 72,11\% dengan kriteria baik. Sikap teliti sebesar 71,63\% dengan kriteria baik. Sikap Tanggung jawab 71,15\% dengan kriteria baik. Sikap ilmiah dengan nilai persentase paling rendah adalah sikap kritis sebesar 69,22 dengan kriteria cukup. Perbandingan diagram hasil persentase skor setiap sikap ilmiah dapat dilihat pada Gambar 1.

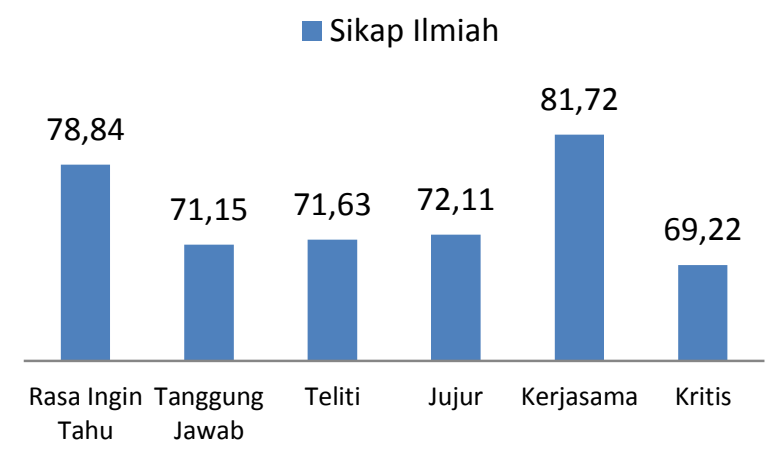

Gambar 1. Diagram Hasil Persentase Rata-Rata Sikap Ilmiah Mahasiswa Calon Guru IPA

Data yang terdapat pada tabel 2 menunjukkan bahwa rata rata terjadi peningkatan pada setiap pertemuan pada setiap indikator sikap ilmiah. Kriteria pada setiap sikap ilmiah menujukkan rata rata dengan kriteria baik.

Sikap rasa ingin tahu menunjukkan rata rata akhir $78,84 \%$ dengan kriteria baik. Kegiatan perkuliahan praktikum Biologi Dasar I pada sikap rasa ingin tahu mengalami kenaikan di setiap pertemuan.. Hal ini terlihat dari sebagian besar mahasiswa berantusias memperhatikan dan mencoba untuk melakukan praktikum.. Sebagian 
mahasiswa pada saat sekolah rata rata jarang melakukan praktikum sehingga para mahasiswa berantusias atau menunjukkan rasa ingin tahu yang besar terhadap kegiatan pembelajaran yang berlangsung. Keingintahuan mahasiswa juga terlihat dari antusias mahasiswa dalam memahami konsep baru dari praktikum yang diterimanya. Sikap ilmiah peserta didik diperlihatkan dari bagaimana mereka memiliki rasa ingin tahu yang tinggi dalam kemampuannya memahami konsep baru yang dipelajari (Yunita, 2012).

Rasa ingin tahu merupakan cara berpikir, sikap, dan perilaku yang mencerminkan penasaran dan keingintahuan tentang segala hal sesuatu yang ingin didengar, dilihat dan dipelajari secara mendalam (Kementerian Pendidikan dan Kebudayaan, 2014). Rasa ingin tahu bagi peserta didik sangat penting ditumbuhkan karena menjadi modal awal dalam pembelajaran. Bagi mahasiswa calon guru ipa STKIP Modern Ngawi memilki rasa ingin tahu yang baik hal ini menjadikan dasar para mahasiswa untuk belajar dan menemukan ilmu pengetahuan mereka.

Sikap tanggung jawab menunjukkan rata rata dengan persentase sebesar $71.15 \%$ dengan kriteria baik. Pertemuan pertama terlihat persentase sebesar 70,19\%, pertemuan kedua $71,15 \%$, pertemuan ketiga $71,15 \%$, dan pertemuan keempat $72,11 \%$. Sikap tanggung jawab dapat terlihat dari beberapa indikator saat kegiatan praktikum biologi dasar I. Beberapa masih memiliki sikap tanggung jawab yang kurang.

Kurangnya tanggung jawab pada beberapa mahasiswa perlu di tingkatkan lagi pada pembelajaran selanjutnya. Sikap tanggung jawab setiap mahasiswa dapat terlihat diantaranya dari pembuatan laporan di setiap kegiatan praktikum. Laporan kegiatan praktikum dikumpulkan setelah seminggu melakukan praktikum. Kenyataannya beberapa mahasiswa masih malas dalam mngumpulkan laporan, banyak yang terlambat dalam pengumpulan laporan. Hal ini dikarenakan mahasiswa masih belum terbiasa dalam penulisan laporan ilmiah. Indikator sikap tanggung jawab kedua yaitu pelaksanaan tugas atau praktikum. Sebagian besar sudah melaksanakan praktikum. Indikator ketiga sikap tanggung jawab adalah aktif berkomunikasi dan mengajukan usul dalam memecahkan masalah. Pada indikator ini mahasiswa sudah terlihat dalam menjawab pertanyaan dosen, mengajukan pertanyaan, berpendapat atau berkomunikasi memecahkan masalah. Indikator keempat adalah penyelesaian praktikum tepat waktu serta bertanggung jawab dalam kebersihan alat bahan praktikum. Beberapa mahasiswa juga masih ada yang terlambat dalam menyelesaikan kegiatan praktikum.

Sikap teliti menunjukkan rata-rata akhir sebesar 72,84\% dengan kriteria baik. Pertemuan pertama terlihat persentase sebesar $72,15 \%$, pertemuan kedua diperoleh persentase $71,15 \%$, pertemuan ketiga diperoleh persentase $74,03 \%$, dan pertemuan keempat diperoleh persentase 74,03\%. Kegiatan praktikum Biologi Dasar I pada aspek sikap teliti mengalami kenaikan di akhir petemuan. Hal ini terlihat dari sebagian mahasiswa yang tekun dalam melakukan praktikum yang kurang sesuai. Mahasiswa mencoba kembali dengan mengulang praktikum jika masih salag atau tidak sesuai. Sikap teliti juga terlihat dari penggunaaan alat yang baik dan sesuai. Ketelitian juga ditunjukkan dari langkah langkah pembelajaran praktikum yang dilakukan secara benar. Mahasiswa juga dapat menjawab beberapa pertanyaan secara tepat. Mahasiswa yang memiliki ketelitian mampu menyelesaikan tugas dengan secara benar.

Sikap jujur menunjukkan kenaikan pada setiap pertemuan dengan rata rata $72,11 \%$ dengan kriteria baik. Pertemuan pertama terlihat persentase sebesar 70,19\%, pertemuan kedua diperoleh persentase $71,15 \%$, pertemuan ketiga diperoleh persentase $72,11 \%$, dan pertemuan keempat diperoleh persentase 72,11\%. Sikap jujur terlihat saat praktikum adanya data yang ditulis sesuai dengan yang telah dilakukan. Mahasiswa tidak memanipulasi data hasil praktikum. Sikap jujur juga terlihat saat mahasiswa mengerjakan tes. Tes dikerjakan sesuai kemampuannya masing masing tanpa bertanya atau melihat jawaban temannya. Berdasarkan data disimpulkan bahwa sikap jujur mahasiswa calon guru ipa dalam kriteria baik dan perlu di tingkatkan lagi karena kejujuran merupakan faktor penting yang perlu diperhatikan dalam mendidik siswanya (B. Uno, 2014).

Sikap kerjasama berdasarkan data diperoleh hasil dengan persentase rata-rata sebesar $81,72 \%$ dengan kriteria sangat baik. Berdasarkan Tabel 2 data diperoleh hasil setiap pertemuan mengalami kenaikan dengan kriteria sangat baik. Pertemuan pertama terlihat persentase sebesar $80,76 \%$, pertemuan kedua diperoleh persentase $81,73 \%$, pertemuan ketiga diperoleh persentase $81,73 \%$, dan pertemuan keempat diperoleh persentase 82,69\%. Sikap kerjasama memperoleh nilai rata rata tertinggi terlihat dari sebagian mahasiswa saat pembelajaran berpartisipasi aktif dalam bekerjasama melakukan praktikum dengan anggota kelompoknya sesuai dengan langkah praktikum yang benar, hasil dari pengamatan diperoleh dari hasil pemikiran bersama. Indikator sikap kerjasama juga terlihat dari adanya pertukaran informasi antara mahasiswa, sebagian mahasiswa yang sudah paham memberikan konsep materi yang sesuai kepada mahasiswa yang belum memahami, pendapat teman dalam kelompok juga didengarkan dan dihargai oleh anggota kelompoknya. Kerjasama secara kelompok dapat dilakukan oleh peserta didik untuk melakukan tindakan sebagai peneliti dalam melaksanakan tahapan proses ilmiah sehingga proses pembelajaran menjadi optimal (Rustaman, 2005).

Sikap kritis pada kegiatan praktikum biologi dasar I menunjukkan rata-rata sebesar 69,22\% dengan kriteria kurang. Pertemuan pertama terlihat persentase sebesar $65,38 \%$, pertemuan kedua diperoleh persentase $70,19 \%$, pertemuan ketiga diperoleh persentase 70,19\%, dan pertemuan keempat diperoleh persentase $71,15 \%$. Sikap kritis memiliki persentase nilai rata rata yang lebih rendah daripada persentase rata-rata sikap ilmiah yang lainnya. Sikap kritis dapat ditunjukkan dari beberapa indikator yang diamati diantaranya yaitu dari kegiatan mahasiswa dalam mendiskusikan hasil praktikum, kebiasaan mahasiswa dalam mencari info sebanyak mungkin. Sikap kritis juga terlihat dari beberapa pertanyaan mahasiswa serta mengemukakakn pendapat hasil dari praktikum. Sikap 
kritis berhubungan erat dengan kemampuan kognitif. Dengan kemampuan kognitif masiswa dituntut menguji suatu gagasan, memecahkan masalah, mengatasi sesuatu kekurangan sehingga akan timbul sikap kritis.

Sikap menurut (Slameto, 2014) merupakan faktor yang mempengaruhi belajar yang timbul secara internal berperan dalam menentukan reaksi terhadap situasi serta menentukan tindakan seseorang. Sikap peserta didik dipengaruhi faktor penting sehingga dapat menentukan sikap belajar. Sikap ilmiah menjadi faktor yang berpengaruh dalam pembelajaran sains. Kegiatan pembelajaran sains menghasilkan produk salah satunya adalah sikap ilmiah.Sikap ilmiah diperoleh berdasarkan pembelajaran, pengalaman, identifikasi, serta peran sekitar. Sikap ilmiah menurut The Liang Gie merupakan kecenderungan seseorang dalam menentukan tindakan atau memberikan tanggapan sesuai dengan hasil dari suatu pemikiraan ilmiahnya (Ertanti, 2010).

Sikap ilmiah diperlukan peserta didik karena dapat meningkatkan motivasi belajar sehingga hasil belajar yang diharapkan dapat optimal. Kurangnya sikap positif yang dimililiki peserta didik dapat menyebabkan hasil yang kurang atau hasil belajar rendah. Sejalan dengan penelitian (Olasehinde \& Olatoye, 2014) bahwa sikap ilmiah berkaitan erat dalam prestasi belajar ipa.Sikap ilmiah yang tinggi akan berpengaruh juga dalam kelancaran berpikir sehingga akan selalu termotivasi untuk selalu berprestasi dan berhasil.

Berdasarkan data dari Tabel 2 menunjukkan bahwa rata rata sikap ilmiah mahasiswa calon guru ipa dalam kriteria baik. Meskipun demikian perlu ditingkatkan lagi sikap ilmiah dalam pembelajaran untuk menunjang hasil pembelajaran yang baik. Salah satu sikap yang masih kurang adalah sikap kritis, hal ini masih perlu ditingkatkan lebih efektif lagi untuk setiap mahasiswa yang nantinya akan menjadi calon guru ipa. Sikap kritis berhubungan dengan kemampuan kognitif mahasiswa.

Sikap ilmiah yang pada mahasiswa calon guru ipa di setiap pertemuan rata-rata mengalami kenaikan, peningkatan ini terjadi dikarenakan mahasiswa lebih terbiasa dengan pembelajaran praktikum biologi dasar yang diterapkan, sama seperti yang diungkapkan Lang bahwa sikap ilmiah akan muncul setelah dikuatkan atau dibiasakan secara terus menerus (Lang \& Evans, 2006). Kegiatan seperti observasi, eksperimen, permodelan, kunjungan di lapangan dapat menumbuhkan sikap positif terhadap sains serta mengembangkan pemikiran kreatif mereka (Şener, Türk, \& Taş, 2015). Sehingga untuk meningkatkan sikap ilmiah diperlukan tindakan yang konsiten dan waktu yang lama. Pembelajaran yang memberikan pengalaman langsung kepada peserta didik dapat menumbuhkan sikap ilmiah peserta didik. Sikap ilmiah dapat dibentuk melalui pengalaman langsung dan nyata dalam percobaan, observasi atau penemuan (Anis Sulviana, A. W. Jufri, 2018). Mahasiswa calon guru sangat perlu mengembangkan sikap ilmiah karena sebagai teladan bagi peserta didiknya kelak Sikap ilmiah yang ditumbuhkan dari pengajaran guru juga akan menentukan minat peserta didiknya dalam keberhasilan dan keinginan untuk terus belajar dalam meningkatkan kemampuan di bidang ilmunya (Erdogan, 2017).

\section{KESIMPULAN}

Berdasarkan hasil penelitian yang dilakukan dapat diperoleh kesimpulan bahwa analisis sikap ilmiah mahasiswa calon guru ipa di STKIP Modern Ngawi pada mata kuliah biologi dasar I diperoleh hasil dengan kriteria baik dengan perolehan skor rata-rata 74,11\%. Persentase rata-rata sikap rasa ingin tahu diperoleh hasil 78,84, sikap tanggung jawab $71,15 \%$, sikap teliti $71,63 \%$, sikap jujur $72,11 \%$, sikapkerjasama $81,72 \%$, dan sikap kritis $69,22 \%$. Sikap rasa ingin tahu memperoleh hasil point tertinggi dengan kriteria sangat baik dibandingkan dengan sikap ilmiah yang lain sedangkan sikap kritis memperoleh hasil yang terendah dengan kriteria kurang.

\section{DAFTAR PUSTAKA}

Abdi, C. O. (2015). Pengaruh Model Pembelajaran Siklus Belajar(Learning Cycle) 7e Terhadap Sikap Ilmiah Dan Hasil Belajar Biologi Peserta Didik Sman 1 Pringgabaya Tahun Ajaran 2015/2016. Mataram: Universitas Mataram.

Anis Sulviana, A. W. Jufri, A. A. (2018). Prosiding Seminar Nasional Pendidikan Biologi ( ISBN : 978602-61265-2-8 ), Juni 2018 Prosiding Seminar Nasional Pendidikan Biologi ( ISBN : 978-60261265-2-8 ), Juni 2018. Prosiding Seminar Nasional Pendidikan Biologi ( ISBN : 978-602-61265-2-8 ), 505-511.

B. Uno, H. (2014). Profesi Kependidikan. PT Bumi Aksara.

Erdogan, S. C. (2017). Science Teaching Attitudes and Scientific Attitudes of Pre-Service Teachers of Gifted Students. Journal of Education and Practice, 8(6), 164-170.

Kementerian Pendidikan dan Kebudayaan. (2014). Materi Pelatihan Implementasi Kurikulum 2013 Tahun 2014. In Badan Pengembangan Sumber Daya Manusia Pendidikan dan Kebudayaan dan Penjaminan Mutu Pendidikan. https://doi.org/10.3406/arch.1977.1322

Olasehinde, K. J., \& Olatoye, R. A. (2014). Scientific Attitude, Attitude to Science and Science Achievement of Senior Secondary School Students in Katsina State, Nigeria. Journal of Educational and Social Research, 4(1), 445-452. https://doi.org/10.5901/jesr.2014.v4n1p445

Riduwan. (2009). Metode \& teknik menyusun proposal penelitian. In Bandung: Alfabeta.

Rustaman, N. Y. (2005). Perkembangan Penelitian Pembelajaran Berbasis Inkuiri dalam Pendidikan Sains. Seminar Nasional II Himpunan Ikatan Sarjana Dan Pemerhati IPA Indonesia.

Şener, N., Türk, C., \& Taş, E. (2015). Improving Science Attitude and Creative Thinking through Science Education Project: A Design, Implementation and Assessment. Journal of Education and Training Studies, 3(4), 57-67. https://doi.org/10.11114/jets.v3i4.771

Slameto. (2014). Developing Critical Thinking Skills through School Teacher Training "Training and 
Development Personnel" Model and Their Determinants of Success. International Journal of Information and Education Technology. https://doi.org/10.7763/ijiet.2014.v4.390

Suharsimi, A. (2013). Prosedur Penelitian: Suatu Pendekatan Praktik (Edisi Revisi). In Jakarta: Rineka Cipta.

https://doi.org/10.1017/CBO9781107415324.004

Zulirfan, Zanaton H. Iksan, Kamisah Osman, S. N. M. S. (2017). Issn 1648-3898 Issn 2538-7138 Take-HomeExperiment : Enhancing Students '. (2007), 828-837.

Abdi, C. O. (2015). Pengaruh Model Pembelajaran Siklus Belajar(Learning Cycle) 7e Terhadap Sikap Ilmiah Dan Hasil Belajar Biologi Peserta Didik Sman 1 Pringgabaya Tahun Ajaran 2015/2016. Mataram: Universitas Mataram.

Bundu, P. (2006). Penilaian Keterampilan Proses dan Sikap Ilmiah dalam Pembelajaran Sains di SD. Jakarta: Depdiknas.
Ertanti, D. (2010). Upaya Meningkatkan Sikap Ilmiah melalui Pembelajaran Berbasis Proyek Project Based Learning pada Materi Sistem Pencernaan Siswa Kelas XI SMA Negeri 2 Bantul. FMIPA UNY.

Ikhsansi. (2014). Sikap Ilmiah. Banda Aceh: Universitas Syiah Kuala Darussalam.

Lang, H., \& Evans, D. (2006). odels, Strategies, and Methods for Effective Teaching. USA: Pearson Education Inc.

Marlina, R. (2013). Pemanfaatan Lingkungan Lokal dalam Kegiatan Laboratorium Berbasis Inkuiri Terhadap Sikap Ilmiah Mahasiswa Calon Guru Biologi. Jurnal Visi Ilmu Pendidikan 10 (1), 1-10.

Suryani, I. (2016). Pengembanagan Instrumen Penilaian Sikap Ilmiah pada Pembelajaran dengan Model Latihan Penelitian di Sekolah Dasar. Jurnal Ilmiah Pedadidaktika.

Yunita, F. (2012). Hubungan Antara Sikap Ilmiah Siswa Dengan Hasil Belajar Fisika Di Kelas XI IPA MA Negeri Kampar. 